\title{
Science communication in Brazil: A historical review and considerations about the current situation
}

\author{
LUISA MASSARANI ${ }^{1}$ and ILDEU DE CASTRO MOREIRA ${ }^{2}$ \\ ${ }^{1}$ Casa de Oswaldo Cruz, Fundação Oswaldo Cruz, Av. Brasil, 4365, Manguinhos, 21040-900 \\ Rio de Janeiro, RJ, Brasil \\ ${ }^{2}$ Instituto de Física, Universidade Federal do Rio de Janeiro, Av. Athos da Silveira \\ Ramos, 149, Cidade Universitária, 21941-590, Rio de Janeiro, RJ, Brasil
}

Manuscript received on May 15, 2015; accepted for publication on June 30, 2015

\begin{abstract}
In this paper, we present a historical overview of the science communication activities in Brazil since the nineteenth century and we analyze the current situation and its main concerns. The principal scopes and tools for science communication discussed here are the following: science centers and museums, mass media and large public events for communicating science and technology (S\&T). In recent years, such activities have had a significant breakthrough in Brazil. Yet, there is still a long way to go in order to deliver a quality and extensive science and technology communication to the Brazilians as well as to achieve a suitable level of social appropriation of knowledge on S\&T by the Brazilian society. Some of the main challenges that we are facing are discussed herein.
\end{abstract}

Key words: science communication, Brazil, history of science communication, public communication of science and technology, science centers and museums, science and media.

\section{INTRODUCTION: THE FIRST STEPS OF THE SCIENCE COMMUNICATION IN THE NINETEENTH CENTURY}

From the 16th to the 18th century, systematic scientific activities and the communication of ideas of modern science were almost nonexistent in Brazil, which at that time was a Portuguese colony of exploitation. The country had a small population, most of which was illiterate, and elementary education remained in the hands of the Jesuits until the mid-eighteenth century. In the 18th century the press and the publication of books were prohib-

Correspondence to: Luisa Massarani

E-mail: luisa.massarani4@gmail.com / lumassa@fiocruz.br ited; therefore the few individuals who had access to new scientific knowledge were exclusive to the dominant social sectors and had that access through education abroad. Throughout this period the colonial economic structure - anchored on slavery and based on the exploitation of natural resources, mining and agricultural products, such as sugar cane - did not require a significant scientific and technical development. The needs of the Portuguese government related to science and technology (S\&T), were connected to economic, political and immediate military interests: navigation, astronomy, cartography, mining, plantations, identification and use of natural products. 
Following by the Pombal Reform, the Academia Científica do Rio de Janeiro (Rio de Janeiro Scientific Academy) was established in 1772 with the aim of being devoted to physics, chemistry, natural history, medicine, pharmacy and agriculture (Marques 2005). In 1779 it closed its doors. Soon after, the Sociedade Literária do Rio de Janeiro (Literary Society of Rio de Janeiro) was created, but was closed in 1794 for political reasons and its members imprisoned and charged under the pro-independence conspiracy of the Colony (Silva 2002). Both associations pretended to disseminate aspects of science among stakeholders of the local elite.

The first, yet still very limited, consistent manifestation of science communication in Brazil occurred in the early 19th century. It was due to an over-riding political motive: the Portuguese Court had arrived in Brazil and it was necessary to create the conditions for the administration of the metropolis and the colony to run. Ports were opened, the ban on printing was discontinued and the first institutions linked to science and techniques were created, such as the Real Horto (Royal Garden) (1808), the Real Academia Militar (Royal Military Academy) (1810) and the Museu Real (Royal Museum) (1818). The first newspapers such as A Gazeta do Rio de Janeiro and $O$ Patriota, published articles and news related to science (Oliveira 1998).

Over the next three decades, the number of publications slowly increased. A few of them, such as the Miscelanea scientifica (1835) and the Minerva brasiliense (1843), published articles on S\&T. Ideas and proposals for the development of science and its communication arose from the pioneering initiative of a few intellectuals. Engineer and professor Cândido Batista de Oliveira advocated the implementation of popular courses of physics and chemistry in his project for creating an astronomical observatory ${ }^{1}$. Evaristo

\footnotetext{
${ }^{1}$ Império do Brasil: Diário Fluminense, 01/02/1828, p. 3.
}

da Veiga, an influential journalist, claimed the importance of natural sciences for the country, particularly physics, botany and mineralogy ${ }^{2}$. These propositions, however, did not find fertile grounds.

In the second half of the 19th century, science communication intensified throughout the world, in conjunction with the second Industrial Revolution. A wave of optimism regarding scientific and technical advancement - expressed through the great Universal Exhibitions that started in 1851 traveled the world and reached the country, albeit on a small scale. The communication of science attempted, as one of its striking features at the time, to highlight the applications of sciences in industrial arts. During this period a great, yet scattered, interest for issues related to science arose among the elite Brazilians. Throughout the 19th century, approximately 7,000 newspapers were created in Brazil, of which about 300 possessed titles linked to science - especially by 1860 , with a peek in 1875 - which clearly demonstrates the increase in interest for subjects related to S\&T (Massarani and Moreira 2002).

Cândido Batista de Oliveira (director), Guilherme Schüch de Capanema, Freire Alemão and Emmanuel Liais edited the magazine Revista Brazileira - Jornal de Sciencias, Letras e Artes (1857). During the first phase of existence of this magazine, from 1857 to 1861, approximately 30\% of the articles were scientific or technical texts, $22 \%$ were reports or documents and $20 \%$ were science communication articles. The remaining articles were essays, poems and short notes. In 1857 Cândido Batista published an article on Foucault's pendulum experiment, which was conducted in Rio de Janeiro on October 1851 (Moreira and Massarani 1997). The original demonstration on the Earth $>\mathrm{S}$ rotation with the use of a large pendulum was made by Léon Foucault in February 1851 in Paris,

\footnotetext{
${ }^{2}$ A Aurora Fluminense, 30/09/1829, p. 1; 21/10/1829, p. 1.
} 
and it aroused great interest. The experiment was repeated in the following months in many countries around the world.

In 1876, the Revista do Rio de Janeiro was launched. According to its editorial, "one of the most effective means to promote education and progress, while providing valuable service to the country which has everything to gain from the spread of Lights, is to communicate ${ }^{3}$ science, literature, arts, agriculture, trade and industry" ${ }^{4}$. Meanwhile, Ciência para o Povo (1881) published articles on health and behavior, such as divorce, female frigidity and sterility. A humor magazine from that time, the Revista Illustrada (1876-1898), written by Angelo Agostini, brought precious illustrations that made fun of D. Pedro II's interest in astronomy, particularly on the astronomical expeditions funded by the government. Similar magazines that positively and ironically focused on S\&T issues were Semana Illustrada (1860-1876) and $O$ Mosquito (1869-1877).

As of 1874, newspapers began to report more updated news about new theories and scientific discoveries, made possible by the submarinemediated telegraph cable link between Brazil and Europe. In the years 1886-1891, the Revista do Observatório, issued by the Imperial Observatory of Rio de Janeiro, circulated monthly. Some scientists, as Luís Cruls and Henrique Morize, participated in its creation and editing. The magazine reported on significant discoveries in the fields of astronomy, meteorology and physics of the globe, but its texts were difficult for the non-specialized public. In 1875, the book Doutor Benignus, by Augusto

\footnotetext{
${ }^{3}$ In Portuguese, the word used here was "vulgarizar", which has no equivalent in English. In Brazil, many other words also have been used, such as "popularizar" and "divulgar". Although we are aware that there is no consensus that some of the words are synonymous, in the paper we prefered to use "to communicate" throught the paper.

${ }^{4}$ Revista do Rio de Janeiro, n. 1, 1876, p. 1.
}

Emílio Zaluar, was published. It was one of the first Brazilian science-fiction books, in which was described a scientific expedition to Brazil 's interior $^{5}$.

National Exhibitions began in Brazil in 1861, with the objective of preparing the country for the forthcoming Universal Exhibitions, what occurred in 1862, 1867, 1873, 1876 and 1889. Despite several limitations that reflected the state of the national "art", they constituted important elements of science communication in its applied aspects. Their ultimate objective was to become a showcase of the industrial and agricultural production of the country. During the first National Exhibition, there was an average of 1,127 visitors per day and the event lasted 42 days ${ }^{6}$. During the second exhibition, in 1866 , the total number of visitors was $52,824^{7}$.

In 1873, the "Popular Conferences at Gloria" began. They lasted two decades and had a significant impact on the intellectual elite of Rio de Janeiro. The subjects that were discussed were varied: glaciations, climate, Earth origin, diseases, alcohol, Darwinism, the role of women in society, education, etc. (Correia 1876, Fonseca 1996). It was there, in 1875, that Miranda Azevedo advocated, the then-controversial theory of natural selection. Some newspapers such as the Jornal do Commercio and the Diário do Rio de Janeiro, would announce the conferences and publish the summaries of the issues discussed.

Founded with the objective of spreading knowledge and the study of natural sciences, the Museu Nacional in Rio de Janeiro developed science communication activities by the 1870 s

\footnotetext{
5 The Editora da UFRJ published, in 1994, a new edition of this book.

${ }^{6}$ Relatório da Primeira Exposição Nacional - 1861. Rio de Janeiro: Typography of the Diário do Rio de Janeiro.

${ }^{7}$ Relatório da Segunda Exposição Nacional de 1866. Rio de Janeiro: Tipografia Nacional, 1869.
} 
(Lopes 1995). According to its director Ladislau Netto, the museum had two main purposes: to collect the riches of Brazil and to instruct the people, inculcating the youngsters with a taste for scientific research. In 1876, public courses, which lasted ten years, started at the museum, with lectures in fields such as botany, zoology, mineralogy, geology and anthropology (Sá and Domingues 1996). In turn, the Paraense Museum, in Belém, directed by Emilio Goeldi, began to organize public conferences in 1896. According to its regulations dating from 1894, the museum should focus on "the study, the development and the communication of Natural History and Ethnology of the State of Pará and Amazonia in particular, and Brazil, South America and the American continent in general"

An important document for understanding the state of science communication of the time was published in 1875 in the Revista Brazileira by the French biologist Louis Couty, who used to work in Rio de Janeiro. Couty advocated the development of experimental sciences in Brazil, mentioned the great expansion of science communication in Europe, and analyzed ways to engage the Brazilian public interest towards science. One of his suggestions was valuing national science (Couty 1879). The analysis of science communication in the second half of the 19th century reveal two clear characteristics. At first, the main stakeholders were men, linked to science due to their professional practices, such as professors, engineers and medical doctors or because of their scientific activities, such as naturalists and astronomers. The second characteristic relates to the predominance of interest in the practical applications of science.

At the end of the 19th century and early 20th century, activities related to science communication suffered a drawback. Conferences and popular courses decreased, involvement of scientists and professors diminished, and so did the number of

\footnotetext{
${ }^{8}$ Regimento do Museu Paraense, 1894, p. 22.
}

magazines and articles which focused on science communication. This relative reduction does not seem to have been an isolated incident within the country. It is correlated with a similar decrease in communication activities at the international context (Bauer 1998, Moreira and Massarani 1999).

\section{THE FIRST DECADES OF THE \\ TWENTIETH CENTURY: A MOVEMENT IN FAVOR OF PURE SCIENCE}

At the turn of the 19th to the 20th century, Brazil still did not possess a tradition of institutionalized and systematic scientific research. During this period some important scientific institutions such as the Instituto Butantan in São Paulo and Instituto Soroterápico Federal (Manguinhos) in Rio de Janeiro were created, driven by urgent public health issues and some strong scientific leaderships. Activities for science communication remarkably increased, mainly in the 1920 s. This was directly correlated with a broad international movement of increased science communication. In Rio de Janeiro, the movement was linked to a group of scientists, among whom were Henrique Morize, Manoel Amoroso Costa, Edgard RoquettePinto, the brothers Osório de Almeida, Juliano Moreira and Teodoro Ramos. They participated intensely in the support of what they called 'pure' science (basic science) and its spread in Brazil. They were professors, engineers, medical doctors and other professionals linked to main scientific and educational institutions whose strategy was the development and institutionalization of research (Moreira and Massarani 2001).

A milestone during this period was the creation, in 1916, of the Brazilian Society of Sciences, which would become in 1921 the Brazilian Academy of Sciences (ABC). The first board of this institution included Henrique Morize (president) and Roquette-Pinto. In 1917, ABC puts forth its first science communication activity: "In order to communicate to Brazil the major scientific 
issues of the current times, the Brazilian Society of Science has decided to initiate a series of public conferences in which the most authoritative experts will address such current issues" ${ }^{\prime}$. In 1923 within the headquarters of $\mathrm{ABC}$, the pioneer Rádio Sociedade of Rio de Janeiro (Radio Society of Rio de Janeiro) was founded by a group of scientists, professors and intellectuals who joined forces to create this new method of communication ${ }^{10}$. It aimed to communicate educational, cultural and scientific topics. Morize was president and Roquette-Pinto was secretary and the radio's main promoter. The Rádio Sociedade featured various programs: in addition to music and information, it broadcasted lectures and courses, including courses of English, Brazilian history, literature, radiotelephony, physics, chemistry and other science topics. There also was a segment for children, with three programs for younger listeners. Upon his visit to Brazil in May 1925, Einstein visited the Radio and gave a brief speech in German, which was followed by a translation into Portuguese. Einstein spoke about the importance of the science communication through the new means of radio communication, as long as it was carried out by qualified personnel ${ }^{11}$.

As it is currently the case with the Internet, there were high expectations with regards to the ability of new media to change the educational situation and contribute to social democratization. RoquettePinto demonstrated a high level of optimism regarding the potential outcomes of the radio use and later of the movies, for the communication of science and culture, especially among illiterate people. It was believed that the radio would enable an inexpensive, easy and fast transfer of knowledge and that it would reach the most distant parts of

\footnotetext{
${ }^{9}$ O Imparcial, 13/10/1917.

${ }^{10}$ Part of the archive of the radio is available at http://www. fiocruz.br/radiosociedade/

11 A Pátria, 8/5/1925.
}

the country. In 1927, about 30,000 households had radio-receiving equipment and about 150,000 people listened to the Rádio Sociedade on a daily basis. Simultaneously, Roquette-Pinto developed activities of science communication at the National Museum. In 1920 he produced the Quadros Didáticos de História Natural (Teaching Charts of Natural History) to be used in classrooms, in addition to setting up several exhibitions. As director of the museum between 1926 and 1935, he emphasized the educational aspects of the museum and created science education programs for school use (Moreira et al. 2008).

Engineer and mathematician Manoel Amoroso Costa was an important science communicator. He was the first to reveal the theory of relativity in Brazil by means of articles in newspapers (1919) and of the book called Introdução à teoria da relatividade (Introduction to the Theory of Relativity) (1922). His posthumous book, As Ideias Fundamentais da Matemática (The Fundamental Ideas of Mathematics) (1929), is a milestone in the literature of science communication for the public in Brazil. Meanwhile, physiologist Miguel Osório de Almeida published science communication articles, such as A mentalidade cientifica no Brasil (The scientific mentality in Brazil), Homens e coisas de ciência (Men and science things) and $A$ vulgarização do saber (Science communication). In the latter, he discussed the importance and challenges of science communication: "Many people seem to doubt the benefit of making the general public aware of the scientific movement. One of the main objections that they raise is in the dangers that a 'half-science' might promote. However, these dangers are more imaginary than real. (...) It is not difficult to instruct without leaving illusions about the limits of this knowledge or about the exact possibilities that such knowledge provides. (...) On the other hand, modern life is increasingly dependent on science and increasingly linked to it. (...) Today, all the industries, agriculture and a great number 
of other professions undergo rapid evolution due to the implementation of scientific methods and processes. Modern technology evolves to a rational state, considerably more precise and with a much greater yield. Scientific communication would result in all becoming familiar with the things of science and, above all, it would result in a useful confidence in scientific methods and an enlightened awareness of the services that they can provide". (Ozorio de Almeida 2002, p. 68-69).

In 1923 Rádio Sociedade created its news publication, a science communication magazine named Rádio, dedicated to the radio culture. It then created another science communication magazine Electron, in 1926, which had a print run of three thousand copies. Electron published the Radio's schedule, issues related to radiotelephony and writings of interest from the scientific community.

Throughout the decade, daily newspapers made room for news related to S\&T, yet without any specific systematic coverage. Key events, such as the visit of foreign scientists, catalyzed this sporadic interest. Einstein's visit to Brazil in 1925 was widely reported by the newspapers in Rio de Janeiro, i.e. O Jornal and the Jornal do Brasil (Moreira and Videira 1995). The press also reported on the trip of Marie Curie to Brazil in 1926, when she visited Rio de Janeiro, São Paulo and Minas Gerais (Esteves et al. 2007). The newspaper O Paiz issued cover-page articles about her conferences in Rio, which were focused on radioactivity. The issue regarding women in science, made evident by the presence of Marie Curie, was highlighted at events and by the media.

During this time, science communication books were published; some of them were translations, such as Henri Poincaré's books. Science collections were created, i.e. the Biblioteca de Filosofia Cientifica headed by Pontes de Miranda. In Rio, the main public conferences related to science were carried out by the Brazilian Academy of Sciences and the Associação Brasileira de Educação - ABE
(Brazilian Education Association), often supported by the French Brazilian Institute of Higher Culture, between 1926 and 1929. These conferences were well attended by the public: they were presented by local scientists and scholars, in addition to some foreign ones such as Paul Rivet and Paul Langevin.

When comparing the science communication in the 1920s with the one carried out at the end of the previous century, one notices that it was more geared towards the communication of concepts and knowledge of basic science and less towards applied science. Another distinctive characteristic of the actions of the 1920s is that they now counted with the organized participation of leading scientists and academics. This clearly indicates how important these professionals thought these activities were. The underlying primary motivation was to create conditions for the development of basic research. Science communication came to play a significant role in the construction of Brazilian science. One goal was to sensitize the government and stakeholders about the importance of Brazilian science and eventually to persuade them to create and maintain scientific institutions, in addition to granting greater social value to the research activity. However, the nature of the science communication was still fragmented and incomplete; it only reached a restricted type of public, thereby reflecting the scientific community's still fragile situation of the time.

In the subsequent period between the $1930 \mathrm{~s}$ and the 1970s, science in Brazil evolved slowly, as did science communication. There were however important transformative events in terms of institutionalization, such as the creation of the Faculty of Sciences initiated in the 1930s in São Paulo and in Rio de Janeiro and the creation of major research institutes in the 1950s. In the scientific context, the National Council for Scientific and Technological Development (CNPq), first public research-fostering agency, was organized in 1951.

Among the actions in science communication, the highlight was the production of movies by the 
Instituto Nacional de Cinema Educativo - INCE (National Institute of Educational Cinema), that had been created in 1937 and directed by RoquettePinto. Between the years of 1930 and 1960, over a hundred films were produced with focus on science education and science communication. Scientists as Carlos Chagas Filho participated in the making of these movies, which were directed by Humberto Mauro. The movies were characterized by a nationalist emphasis and didacticism, given their objectives linked to formal education. Like the radio was in the previous decade, the movies were seen as a tool for the democratization of information and for the revitalization of national education, which needed to be based on a basic scientific training. Roquette-Pinto's dream was ambitious: "My wish is to spread the knowledge of the wonders of modern science within the popular classes. (...) I want to remove science from the exclusive domain of the wise to hand it over to the people" (Lins 1956, p. 117).

In the decades 1920-1940, Monteiro Lobato produced books that - even to this date - have a high level of acceptance among children. Science has almost always had a strong presence in his books, as in the series of the Sitio do Pica-Pau Amarelo, that later turned into a TV show. In tune with the context of that time, science was presented under the perspective of being redemptive and as a tool for overcoming underdevelopment. Another important author was the math teacher Júlio César de Mello e Souza, alias Malba Tahan, who published many books on curious and historical aspects of mathematics and that included mathbased hobbies. O homem que calculava (The man who calculated) (1938) is to date a top seller within this field. It has achieved over dozens of editions in Brazil, with over 500,000 copies sold, in addition to being translated into many languages. In turn, Aparicio Torelly, the Baron of Itararé, was showing his humorous side, impregnated with references to the presence of S\&T in everyday life.
In the 1940s, the production of the biologist and science communicator José Reis, one of the pioneers of science journalism in Brazil, emerged. He began his activities as a writer of science topics in the Folha da Manhã (later called Folha de São Paulo), with a Sunday column that ran for over five decades. He collaborated in magazines, he wrote books for children and youngsters and he developed radio programs for the science communication. In his honor, in 1978, CNPq created the José Reis Award for science communication in order to annually reward individuals and institutions who have developed relevant work in this area. José Reis was also one of the founders in 1948 of the Sociedade Brasileira para o Progresso da Ciencia - SBPC (Brazilian Society for the Advancement of Science). Among the objectives of SBPC, similar to its American and British counterparts that had been created in the previous century, is to contribute to science communication. It became, especially as of the 1980 s, the main entity to promote events and publications focused on science communication.

After World War II, new spaces for science communication emerged in newspapers, especially in Rio and São Paulo, some of them creating science sections (Esteves 2011). The afternoon newspaper from São Paulo called A Noite stood out for publishing long articles about science, many of which had highlights featured on the cover. These texts presented the regular activities of Brazilian research institutions and advocated for better conditions for science practice. In the beginning of the $1950 \mathrm{~s}$, the overall public interest for the physical sciences awakened, due to discussions regarding the use of nuclear energy for military and civilian use and also to the fact that the Brazilian scientist Cesar Lattes participated in the discovery and identification of the pi-meson in the years 1947-1948. Newspapers and magazines of broad circulation, such as $O$ Cruzeiro and Manchete, published many stories about the issue, emphasizing the activities of Brazilian institutions 
and researchers and the advances made in the field of nuclear energy. An example of the popular interest aroused by the works of Cesar Lattes can be found in the lyrics of the samba Ciencia $e$ arte (Science and Art), written by Cartola and Carlos Cachaça, for the Mangueira samba school (1948), in which the scientist and the painter Pedro Américo are honored. The influence of the atomic bomb and its consequences led to many references in the Brazilian literature of this period, particularly in the poetry of Carlos Drummond and Vinicius de Moraes.

The supplement "Ciência para todos" (Science for All) was published monthly by the newspaper A Manhã, between 1948 and 1953. Fernando de Souza Reis, with the participation of the active science-communicator biologist Oswaldo FrotaPessoa and other scientists edited it (Esteves et al. 2006). Its editorial line was renowned for its appreciation of the Brazilian science, for encouraging the institutionalization of research activities and for its particularly positive outlook on science and scientists. A similar approach occurred on the Sunday page called "Ciência" ("Science") of the Jornal do Commercio, published between 1958 and 1962 (Moreira and Massarani 2011). Under the coordination of Walter Oswaldo Cruz and supported by a conjunction of scientists and professors, it emphasized the role of science for the development of Brazil. Its presentation would say: "This supplement, inaugurated today, is a mild gesture to awaken the country on this morning of its industrialization era. Its soft villager's sleep of citizens from a few centuries ago, needs to end since the machines wait them for multiplying the richness to be shared, by means of the industry. Brazil will not develop without technicians, and technicians are the human product of science. The development, the prestige, the understanding and the advancement of science will open the only path towards the growth of real economic independence of our country"12.

\footnotetext{
${ }^{12}$ Jornal do Commercio, 11/16/1958, Third Section, p. 3.
}

The science museums in this period were linked to natural history, like the National Museum and the Goeldi Museum, or to specific technological collections, i.e. the Museum of Gold. In general they fell within the typical model of museums endowed with material objects intended for preservation, static displays and no hands on activities. In the 1950s and 1960s in Rio de Janeiro and São Paulo, proposals emerged for science museums with more dynamic characteristics ${ }^{13}$. In São Paulo the newspapers reported on proposals for the creation of a Science Museum and a Planetarium in the Ibirapuera Park, since $1954^{14}$. The Planetarium of São Paulo, the first in Brazil, would be set up in January 1957. The Palais de la Découverte (Paris) would serve as a model for Carlos Chagas Filho to, once again, make a proposal to the various authorities of Rio de Janeiro. In the 1950s, he began negotiations with the rector of the UFRJ (Federal University of Rio de Janeiro), Pedro Calmon, to create the university's science museum. In 1961 he proposed to the State governor to build an interactive science museum in Rio de Janeiro, the Palace of Sciences, similar to the Chicago Museum that he had been able to visit in 1946, and similar to the Palais de la Découverte. The project had the objective of "spreading scientific knowledge into the public and enhancing secondary education, by providing students with basic ideas mainly with regards to practical demonstration". The museum intended to "present issues related to physics, genetics, nuclear power, tropical diseases and a few aspects related to oil ${ }^{15}$ ". Carlos Lacerda favorably

\footnotetext{
${ }^{13}$ Since the 1920 s, Roquette-Pinto planned on creating a science museum with more dynamic characteristics, similar to the Deutsches Museum, as reported by Francisco Venâncio Filho, who also was a promoter of the idea of interactive museums. Mentioned on Alberto Venâncio Filho, Francisco Venâncio Filho: Um educador brasileiro 1894-1994, Rio de Janeiro: Nova Fronteira, 1995.

${ }^{14}$ Diário da Tarde, 2/6/1954.

15 Jornal do Commercio, Third Section, p. 1, 5/14/1961.
} 
received the proposal, but the museum was not created. Previously, a working group between the Brazilian Center for Physics Research (CBPF) and the Municipality of the Federal District had been created in Rio de Janeiro and an agreement was signed in November 1956 for the installation of the Science Museum, which would also have a planetarium and an aquarium, in Guanabara ${ }^{16}$. But none of these attempts succeeded (Valente 2008). The Planetarium of Rio de Janeiro was opened in 1970 by the State Secretary of S\&T and at which time the creation of a S\&T Palace was mentioned again. In the initial plan of the University of Brasília the creation of a Science Museum was included ${ }^{17}$. This initiative has been revisited several times over the years. Finally its creation was made official in $2014^{18}$, but the museum does not exist yet.

In the 1960s, under the influence of transformations in science education in the United States, a renewed educational movement - based on the importance of experimentation for the teaching of science - began in Brazil. Among other consequences, this movement led to the emergence of science centers throughout the country. Despite being linked to formal education, to some extent these centers contributed to the activities of science communication and stimulated the creation of science fairs and the construction of hands-on science museums in the decades that followed. José Reis, Frota Pessoa and other scientists, professors and science communicators were among some of the prominent people who participated in these fairs. It was then (1964) that the military coup occurred, which would result in profound social, economic, educational and scientific effects on the country and would greatly decrease the momentum of several of these initiatives.

\footnotetext{
${ }^{16}$ Jornal do Brasil, 5/24/1956; Diário da Tarde, 11/3/1956.

${ }^{17}$ Jornal do Brasil, 5/24/1961, p. 11.

${ }^{18}$ Decreto N. 34.838, 13/11/2013 (Governo do Distrito Federal).
}

An important dimension of science journalism throughout the world in the 1970s, could be credited to Spaniard Manuel Calvo Hernando, who inspired several Latin American countries to create science journalism associations and science sections within newspapers (Massarani et al. 2012). He played an important role in Brazil in the training of science journalists, by delivering a course in 1972, at the University of São Paulo. Within this context, the Brazilian Association of Science Journalism was created in 1977. According to Julio Abramczyk, who chaired the association after its first president José Reis, the efforts of this association in its first decade were largely geared towards attracting professional journalists ${ }^{19}$.

\section{THE RECENT DECADES: NEW MEANS OF COMMUNICATION, SCIENCE MUSEUMS AND PUBLIC POLICIES FOR THE S\&T COMMUNICATION}

From the 1980s until the present day has been a period of continuous growth in science communication, and it has been particularly rich in diversified experiences. Yet, Brazil is still far from showing an ample, extensive and qualified action, one that would reflect consistent public policy support in this field.

In the 1970s, dictatorship severely hit sectors of the scientific community, forcing many people into exile, including scientists and students ${ }^{20}$. Within that scenario, the SBPC took on an important role of government resistance. In particular, its annual meetings clearly became the grounds of an opposition movement and had political impact on the public and on mass media (Fernandes 1990). In favor of democracy and in defense of an alternative development for Brazil, this movement

\footnotetext{
${ }^{19}$ Interview granted by Julio Abramczyk to Luisa Massarani on $01 / 04 / 2012$.

${ }^{20}$ See Ciência e Cultura, Year 66, n. 4, Núcleo Temático: Universidades na Ditadura, p. 20-53, 2014.
} 
supported the idea of science being an important tool to overcome underdevelopment and to address the social issues faced by the country at that time. SBPC's Annual Meetings also began to play an important role in science communication, attracting thousands of students, scientists, teachers, and other participants, whose numbers reached over 20,000 people per meeting. The mobilization around SBPC, in the 1970s and 1980s, resulted in the creation of groups of scientists, professors, teachers and students who started movements in several parts of the country. They began to organize seminars and science communication events, to promote the implementation of scientific-cultural places and to create new science communication tools. A prominent action was the creation of the Ciência Hoje (Science Today) magazine in 1982. Ciência Hoje later became a large complex, which included printed and online publications and a magazine for children (Ciência Hoje das Crianças) that had widespread circulation and an extensive acceptance among public schools.

In the following years other science communication magazines emerged. From 1981 to 1984, Abril Publishing launched a Brazilian version of the Science Illustrated magazine, published by Reader's Digest. In 1987, the same publisher created the Superinteressante magazine, within the guidelines of the Spanish magazine Muy Interesante. In 1991 the magazine Globo Ciência, now called Galileu, was launched. However commercial interests, and a distorted vision regarding what science communication really is, led to the unfortunate current situation: the scientific credibility of many of the publications was poor and often favored pseudoscience. In 2002, the Scientific American Brazil was created, which includes articles written by Brazilian scientists and journalists. Recently, several research-support State-Foundations (FAPs for Fundação de Amparo à Pesquisa), such as Fapesp (State of São Paulo), Faperj (Rio de Janeiro), Fapemig (Minas Gerais) and Fapeam (Amazonas), began publishing science communication magazines.

Despite its high reach throughout Brazil, radio broadcast is still rarely used to cover and debate S\&T issues. There were innovative initiatives such as the $E$ por falar em ciência program, broadcasted by Radio MEC between 1992 and 1997 (Werneck 2002). As of today, the total number of specific programs focused on S\&T is about three dozen, most of which being from public stations, in general short-range university stations. In regard to the production of science communication programs for its radio and TV station, a university which has excelled in recent years is UFMG (Universidade Federal de Minas Gerais).

The first attempt at creating a science program for television occurred in 1979, when Nossa Ciência was aired by the governmental channel in Rio de Janeiro. It lasted only 10 episodes. Globo Ciência, the program of the TV Globo channel and the Roberto Marinho Foundation, was more successful: it was created in 1984 and lasted until 2014, both on open broadcast channel and on Canal Futura. In the beginning Globo Ciência had a more journalistic format than lately, but since its start it kept alternating between phases of greater and lesser audience viewership and kept periodically rethinking its goals and its formats to disseminate science. In its wake there emerged other similar programs, which also dealt with $\mathrm{S} \& \mathrm{~T}$ issues, such as the Globo Ecologia, Globo Rural and the Globo Universidade. These programs have recently been merged into a more comprehensive program. The TV Cultura of São Paulo aired several programs of science communication. Some of these programs were produced in Brazil, such as the Minuto Científico (1996-1997) or Ver Ciência (20022005), while others aimed for the younger public, such as The World of Beakman (1994-2002), were translated into Portuguese. The Tome Ciência program, with news and interviews on S\&T issues, emerged in 1987 in the TVE channel and lasted 
until 1990. It resumed in 2004 and is currently aired on several university and legislative channels. Some state or university channels, such as the $T V$ Educativa of Espírito Santo or the UFMG TV, have been airing science communication programs.

Furthermore, the Projeto Ver Ciência - Mostra Internacional de Ciência na $T V$, that was created in 1994 consists of an annual mostra of TV programs focused on S\&T, that are produced in Brazil and abroad. As of 2004, this annual airing became part of the National Week of S\&T and, as a result of this event, it had spread throughout all the Brazilian states. Several cable channels have programs related to $S \& T$; yet, the access to these programs is limited to a relatively small portion of Brazilians. Even though there are only a few science communication-focused programs on TV, science finds space in other programs. This fact becomes relevant if we consider that television is present in $97 \%$ of Brazilian households ${ }^{21}$. As examples, in the TV news casts, news relating to science occupied an average of $7.3 \%$ of the daily time of Jornal Nacional from April 2009 to March 2010 (Ramalho et al. 2012); and $\sim 3.8 \%$ of the daily broadcast (Reznik et al. 2014) of Repórter Brasil (TV Brazil) over the same period of time. Other television programs like Fantástico also convey issues of S\&T (Medeiros et al. 2013). Nonetheless, the quality of the science presented in the mass media still does not reach adequate levels, even though it has improved over recent years. "Science is often presented as a spectacular occurrence, in which scientific discoveries are episodic and performed by particularly gifted individuals. Real or imagined applications of science are given great emphasis, but the process of its production, its context, its limitations and its uncertainties are usually ignored and simplified conceptual models regarding the relationship between science and the public, prevail". (Moreira 2008, p. 89-98).

\footnotetext{
${ }^{21}$ National survey carried out by IBGE, in 2011.
}

In the 1980s new sections devoted to science appeared in the pages of the daily newspapers, yet throughout the following years they underwent intermittent questioning processes which resulted in reduced or increased contents. National newspapers with the largest print runs, such as O Globo, Jornal do Brasil, Folha de São Paulo and $O$ Estado de São Paulo, and local newspapers such as the Jornal do Commercio in Recife, Correio Brasiliense in Brasília and Zero Hora in Porto Alegre, have provided space for the science communication and have, or have had, expert journalists in media coverage of science (Almeida et al. 2011). At a national level, space provided in newspapers for science reports is generally limited and very few are the journalists with adequate competence in the field. However, some issues have generated general public interest, due to their major impact on the public (such as GM food, climate change or embryonic cells) and have lead to an increase of space dedicated to S\&T in different sections of newspapers (Massarani et al. 2003). A significant portion of the coverage of S\&T issues follows the agenda of developed countries. Several newspapers provide little space for national scientific production and in this case, as a rule, to the regional context. Such a fact does not seem to be as prominent on TV, especially on TV news, which often addresses local scientific production (Ramalho et al. 2012). Discussions about S\&T policies and communication about the results of public actions related to science communication are often excluded of the news coverage. This causes the public sphere to be less influential than it could be in the discussion about public policies in this field.

The use of the Internet for science communication in Brazil mainly occurs when science centers and museums, scientific institutions, research groups on science communication and a few governmental agencies undertake the initiatives. With regards to blogs, there is an increased number of 
blogger's initiatives. A growing engagement of scientists and science communicators is observed, similar to what happens in Europe and United States, yet at a considerably lower level. The ScienceBlogs Brasil ${ }^{22}$ gateway is associated with the largest gateway of science blogs in the world and has about 40 blogs. The use of social media networks, such as Facebook, for science communication has grown considerably in recent times and tends to dominate in the communication for quick information; however, its full potential is still unexplored. The quantitative use of the Internet to search for information about S\&T is already close to the use of TV for the same purpose. Webvideo has emerged as a tool to potentially have a significant impact on the dissemination of information about S\&T, and new communication tools and procedures on the horizon will certainly arise.

The quality of the science coverage significantly varies according to the means of the mass media, but in general it can be said that Brazilian science journalism is still largely based on a limited vision of scientific activity, with little mention of the context of its production and of its social impacts. The image of the scientist that appears in the media is predominantly male, which suggests a stereotypical role of men and women scientists: while men go out to literally explore other worlds, women take care of health and the body (This is the case, for example, of the Jornal Nacional and the Fantástico program, as indicated by Castelfranchi et al. 2014).

Let us now take a look at the science centers and science museums. As of the early 1980s, they began to be created in the country. This followed an international trend, with one important feature being interactivity with the public. Among the first science museums of this kind were the following: the Museu de C\&T da Bahia (1979), the Centro de Divulgação Cientifica e Cultural (1980), linked

\footnotetext{
${ }^{22}$ http://scienceblogs.com.br/
}

to the University of São Paulo in São Carlos, and the Espaço Ciência Viva (1982) in Rio de Janeiro. The latter was inspired by the Exploratorium of San Francisco (USA), and had the collaboration of members of its staff. It actually had the first handson exhibits in Brazil. In 1985 in Rio de Janeiro the Museu de Astronomia e Ciências Afins was created, an institution which was devoted to the history of science but also had activities focused on science communication.

In the city of São Paulo Estação Ciência was created in 1987 by CNPq. It is currently linked to University of São Paulo. One of the country's largest science museums is the Museu de $C \& T$ of the Pontifical Catholic University of Rio Grande do Sul in Porto Alegre. In the year 1967 the embryonic museum owned a collection of animals, rocks and minerals collected by biologist Jeter Bertoletti. In 1993, the museum inaugurated a new building where it is located today, with a display area of 17,500 square meters. It became one of the most visited museums in the country. In 1999 the Museu da Vida was created at the Oswaldo Cruz Foundation in Rio de Janeiro. It was medium-sized and focused on the interface of science and health. In Pernambuco we can highlight the Espaço Ciência (1994), linked to the State Department of S\&T and Environment, which possesses a large open area between the city of Recife and its close neighbor Olinda. More recently in São Paulo, the Catavento Cultural e Educacional (2010) was created. It is a social organization of the state government that became the most visited museum in the state. A characteristic of almost all these museums and science centers is that a significant portion of the visitors (about $60 \%$ or more) consists of school children.

Considering the size of the country and its population, the number of scientific-cultural spaces in Brazil is still low in comparison to more advanced countries. Currently there are about 260 museums registered in the 2015 Brazilian Guide of Museums 
and Science Centers. They are specifically devoted to S\&T, or have greater connections with scientific issues and practices, such as the natural history museums, hands on science centers, botanical gardens, zoos, aquariums, planetariums, environmental parks, observatories, etc. (Almeida et al. 2015). Most of them are small and medium in size and have very low levels of interactivity; very few of them are big enough to receive over 100,000 visitors a year. They are mostly financed by public funds with very limited private participation.

Furthermore, Brazil's museums geographical and social distribution is very uneven, with greater concentration in the wealthier areas of large cities of the Southeastern part of the country. We can observe that these institutions have a limited capacity to boost science communication on a large scale, considering the size and the diversity of the Brazilian population. These museums' attendance is small: the percentage of visitors used to be about $8.3 \%$ of the Brazilian population in 2010 - less than half the average of European countries ${ }^{23}$. Yet the total number of people that visit museums and S\&T centers doubled since the last survey in 2006, when it was evaluated at about $4 \%$. The 2010 survey indicated that a large number of Brazilians (28\%) visit locations for contact with nature, through botanical gardens, zoos and environmental parks. Very few of these spaces, however, with laudable exceptions, promote science communication and environmental education programs. Policies and public actions taken in favor of this promotion would greatly contribute to engage a large number of Brazilians in activities focused on environmental education and science communication.

From the point of view of professionals and institutions related to science communication

\footnotetext{
${ }^{23}$ Public Perception of Science and Technology in Brazil, data from the national survey conducted by the Ministry of Science and Technology and the Museum of Life, released in 2010. Data available on: http:/www.museudavida.fiocruz.br/media/ enquete2010.pdf (accessed on 12/4/2015).
}

actively organized, some events stand out. In addition to the Brazilian Association of Science Journalism, which was created in 1977, there exist representative bodies for zoos and aquariums (1977), botanical gardens (1991), planetariums (1996). The Brazilian Association of Science Centers and Museums was created in 1999. In a larger context, the Red de Popularización de la Ciencia y la Tecnología en América Latina y el Caribe (RedPOP) (Network for the Communication of Science and Technology of Latin America and the Caribbean) was created in 1990, as an interactive network that linked science communication centers and programs of the sub continent. Some Brazilian science communicators stood out over the last few decades for their activities while receiving the Kalinga Prize, an international prize granted by Unesco: José Reis (in 1974), Oswaldo Frota-Pessoa (1982), Ennio Candotti (1988), Ernest Hamburger (2000) and Jetter Bertoletti (2005).

Starting from 2003, institutions, scientific organizations and stakeholder groups greatly spurred the establishment of broader public policies in science communication. This occurred when organized movements and activities focused on valuing and strengthening communication actions. The Department of Popularization and Diffusion of S\&T was established in 2004, within the Ministry of Science, Technology and Innovation (MCTI) as one of the tools of this public policy. This lead to a significant increase in the incentives for science communication, including financial support in the arena and the establishment of a national coordination for many of these initiatives. As a result over the following 10 years, nearly three dozen calls were made through $\mathrm{CNPq}$ to support science communication projects. Among these projects there was the creation and development of science centers and museums, the development of science olympiads, science fairs and exhibitions, and other activities. There are now about 10 national science olympiads, such as in astronomy 
and astronautics, physics, mathematics, chemistry, history, health and environment. They are organized by scientific societies and/or research institutions. The noteworthy Brazilian Mathematics Olympics of the Public Schools (OBMEP), has a huge scope and educational impact, since it reaches nearly 20 million students, rendering it the largest event of its kind in the world. One of the supported programs for popularization of science, backed initiatives of "mobile science" with trucks, buses, vans etc., planned to reach remote areas of the country. Several state funding agencies also launched calls for science communication over the past years and promoted initiatives within their states, in line with the federal actions and often linked to them. Among these states are Minas Gerais, Rio de Janeiro, São Paulo, Bahia, Amazonas, Rio Grande do Norte, Espírito Santo, Ceará, Maranhão and Rio Grande do Sul.

The National Week of Science and Technology (SNCT) was created by presidential decree in 2004 nationally coordinated by the MCTI, with the collaboration of other institutions and scientific organizations. It's objective is to get the public, especially children and teen-agers, engaged in issues and activities related to science and to encourage creativity, scientific attitude and innovation. Universities, research institutions, schools, science centers and museums, funding agencies, the media, NGOs, businesses, etc., have increasingly been participating to the SNCT. A decentralized structure allowed the stimulation, involvement and participation of State and locallevel public institutions of research and education. In the National Week of Science and Technology of 2014 , about 108,000 activities were recorded in 902 Brazilian municipalities ${ }^{24}$. These data, in terms of numbers of events and territorial extension, makes the SNCT perhaps the biggest integrated

${ }^{24}$ See http://semanact.mcti.gov.br/web/snct2014 (accessed on 30/04/2015). event of science communication in the world. In some states and municipalities, local S\&T weeks have been officially created, integrated with the SNCT. The SNCT still faces major challenges regarding its expansion and improvement, such as reaching more schools and municipalities, reaching low-income sectors of society, further involving scientific and academic community and making the activities performed be more innovative, dynamic, interactive and participatory.

In recent years, many celebrations regarding the international years proclaimed by the United Nations/UNESCO have been supported by the government and carried out by scientific societies and educational and research institutions. As such, many initiatives were developed in the World Year of Physics (2005), the International Year of Astronomy (2009) and the International Year of Chemistry (2011), that reached millions of people throughout the country.

Another significant political milestone was reached when science communication was included as a course of action in three key documents for the formulation of public policies, namely the National Plans for ST\&I for years 2007-2010 and for 2011-2015 as well as in the so-called Blue Book, a summary of the discussions of the 4th National Conference on ST\&I, held in May 2010 (Livro Azul 2010). One of the major challenges for the country in the next decade, which was indicated by the Conference, is to promote a radical change in the science education, in addition to expanding and improving the actions focused on communicating science to the general public. In 2009 , the CNPq, one of the leading governmental funding agencies of the country, created a Science Communication Advisory Committee to support and decide upon science communication projects. Furthermore, CNPq also created in the Lattes Platform, an online CV platform that records the scientific production and other researchers' activities throughout the country, a specific section for ac- 
tivities focused on education and popularization of S\&T. Another important indicator of how activities of science communication are increasingly being valued, is the fact that they are now present in the program of the National S\&T Institutes, created by the MCTI (CNPq) with several FAPs in 2008. The program aims to articulate and mobilize researchers throughout the country, internationally boost competitive basic and fundamental research, encourage scientific and technological research, promote innovation and entrepreneurship, and also establish programs that contribute towards improving science education and the public engagement in science.

Over the last few years, the interest for science communication in universities and research institutions increased significantly, with the creation of several groups throughout Brazil. The Ministry of Education created in 2003 a National Outreach Programme (ProExt), geared towards public institutions of higher education, to support university outreach, including science communication activities. In most cases, however, only isolated individuals or small groups are active, with little institutional support and little interaction with the institutions themselves. When we analyze the higher education offered to specialists in this field, the situation reveals itself to be even more fragile, even though it is improving, with a great dispersion of the courses. The number of theses and dissertations in science communication topics has grown, especially over the last two decades. According to the records of Capes (Foundation of Ministry of Education, $M E C$, in charge of post-graduate grades), there were 279 theses and dissertations written in this field from 2010 to $2012^{25}$. Many of them are developed in

\footnotetext{
${ }^{25}$ The Brasiliana site (http://www.museudavida.fiocruz.br/ brasiliana/), developed within the Museum of Life, devotes a section to this type of academic production produced within the country, and it already amounts to several hundreds of monographs, dissertations or theses; there, you can access the full texts of these materials.
}

courses that do not possess disciplines in science communication or expert supervisors in the field.

In contrast to this general background of science communication - growing, but yet still fragile - Brazilians declare considerable interest in S\&T issues. According to the 2010 survey on public perceptions of S\&T in Brazil, the population's interest in this subject is similar to their interest in sports or economics ${ }^{26}$. The greatest declared interest was in issues of medicine and health (42\% very interested, 39\% interested) and on environmental issues (46\% very interested, $37 \%$ interested). The percentages of interest in S\&T are the following: $30 \%$ very interested and 35\% interested; which can be compared to the $36 \%$ and $26 \%$ indicated for sports. According to the survey, however, the level of available information on S\&T is far below the level of interest revealed, with only around $10 \%$ of Brazilians reaching a high level of information. Brazilians with higher educational levels, and belonging to social classes with higher incomes, have more access to information on S\&T in all the mass communication media. There is a great lack of knowledge regarding local Brazilian scientists and Brazilian institutions that are doing scientific research; the vast majority (about 85\%) of the people interviewed could not name any research institution of the country nor an important Brazilian scientist.

There is a noticeably positive and optimistic vision with regards to the role of S\&T. Based on this national survey, Castelfranchi et al. (2013) indicate that optimistic attitudes about S\&T do not depend in general on the educational level or on the information declared or accessed by those people. Individuals with little schooling and low levels of information generally have positive attitudes;

\footnotetext{
${ }^{26}$ Public Perception of Science and Technology in Brazil, data from the national survey conducted by the Ministry of Science and Technology and the Museum of Life, released in 2010. Data available on: http://www.museudavida.fiocruz.br/media/ enquete2010.pdf (accessed on 12/4/2015).
} 
whereas people with higher education and greater access to information often have diverse attitudes, being optimistic in some respects, but are more critical in others. The overall positive view of the role of S\&T and the expressed confidence in scientists do not prevent the public from being aware of the importance of having the whole society participating in the definition of S\&T policies. However, this awareness has not lead to a more active engagement of authorities in chasing a greater social participation in decision-making.

\section{CURRENT CHALLENGES OF SCIENCE COMMUNICATION IN BRAZIL AND FINAL CONSIDERATIONS}

We have shown that in recent years, the activities of science communication have undergone a significant expansion in Brazil, despite the many major limitations that still linger. Although rare in the country, there already exist some diagnostics on the current framework of these activities, including their scope as well as their impact (Moreira 2006). However, we lack detailed analyses with expanded data and perspectives, particularly about the quality of actions that would enable the drafting of consistent public policies for the next decade. We shall not attempt such task here, which demands more in-depth research and collective reflections than those already made. An excellent example of this type of diagnosis - which could serve as an inspiration for a more global and prospective assessment of the field in Brazil - was made in the United States by the Committee on Learning Science in Informal Environments, of the National Research Council of the National Academies. This Committee produced a comprehensive study on the state of the art of public communication in S\&T (Bell et al. 2009).

We will limit ourselves to indicating, in a synthetic way, a series of general challenges that, in our opinion, should be faced with tough decisions, adequate resources and enthusiasm from research- ers and professionals from educational and research institutions and from federal and local authorities, involved in science communication. We shall do this, basing ourselves on discussions held in congresses and conferences, particularly the Fourth National Conference on ST\&I - IV CNCTI (Livro Azul 2010). The science communication activities are strongly correlated with the quality of basic education, especially science education, for which the IV CNCTI indicated the need for a real "revolution", given the enormous shortcomings in the scientific education of most young Brazilians. Such activities can contribute also to the improvement and modernization of the teaching of science at all levels, with emphasis on methods and practices that enhance and promote creativity, experimentation and inter-discipline.

The main challenges for science communication can be divided into three parts. The first one is to reach the entire Brazilian population. A clear goal is to encompass a much broader sector of the population than what has so far been achieved, which is of about $20 \%$. The objective would be to increase this number greatly, to reach middle sectors, poor and excluded sectors, those in the urban and rural areas, which include over 150 million people. A challenge of this magnitude requires time, resources and a lot of trained people. An important action in order for this to occur, will be to promote science communication in a network, while expanding, improving and integrating science centers and museums, associated to a less unequal (both regionally and socially) distribution, as well as a closer interaction with the formal educational system. Public events for the science communication, in particular the National Week of S\&T, should be extended to all corners of the country. As other stakeholders, those involved with the public communication of science should go where the people are. Another aspect, within the goal towards a greater social engagement, is to use the mass media in a much more intense and qualified way, particularly Internet and 
social networks. Furthermore, there is the need to greatly expand the science communication in the public channels and within the research institutions.

Public policies constitute the second part of the challenges for the development of science communication. Despite the advances of the last decade in terms of encouragements and resources from the federal and from several state governments, public policies still are incipient. Existing structures need to be strengthened and new stimulatory policies should be created, continuity and expansion of means and resources are needed. Science communication has already entered into several governmental agendas and in many educational and research institutions. Politically, however, this has not been done to the necessary extent and to the level of investment inflow that would be needed to get a more socially broad, inclusive and qualified performance (Moreira 2006, Ferreira 2014).

The IV CNCTI placed public communication of S\&T as a highlight in the Strategic Axis "ST\&I for Social Development", and the main challenges were outlined there (along with the overall goals) with proposals to overcome them. The recommendations for the public policies, in addition to the proposal to establish a National Program for the Popularization and Social Appropriation of ST\&I for the next decade (Livro Azul 2010, p. 52-54) are the following: 1) Encourage the institutionalization of the field and the increase of resources allocated to it, while seeking partnerships with the private sector; 2) Create a National Agency for Public Communication of ST\&I, with an autonomous structure, as in other countries, such as Portugal; 3) Establish a legislation that promotes and encourages science communication in the country, as it is the case in China, which enables incentives for investments in the field; 4) Allow a greater autonomy in the management and financing of teaching and research institutions, science centers and museums and public communication agencies.
A drastic decrease in the stifling bureaucracy that plagues S\&T and its communication in the country is not a minor challenge, neither in terms of difficulty nor in terms of importance.

The third aspect of the challenge is related to the improvement of the quality of science communication being conducted. One goal is to increase and improve the training of science journalists, science communicators and scientists, as well as academically valuing these activities. A greater engagement of undergraduate students, particularly those in the fields of science and engineering, in participating in public communication actions of S\&T should be reached. With regards to science centers and museums, some of the permanent challenges that remain are to innovate and incorporate new technologies into their practices, to increase accessibility, to encourage public engagement in big issues of science and society and to improve the training of their staff and explainers (Marandino 2005). It is hoped that innovative initiatives be stimulated and supported, such as the new path for natural science museums, linked with environmental and social concerns ${ }^{27}$.

Still in their early stages, more studies and analyses are needed on strategies, practices and impacts of the outreach activities of S\&T, on characteristics, attitudes and expectations of the audience and on public perceptions of S\&T. Academic assessment of further education activities, particularly in the field of science communication, is still low, despite some recent actions of universities and funding agencies. Such actions should be encouraged. Cooperation with other countries, through partnerships with groups and researchers from abroad who conduct research and high quality science communications, can also provide advances and significant improvements for this field in Brazil, particularly in the training of qualified personnel.

\footnotetext{
${ }^{27}$ A nice example is the Museum of Amazonia (MUSA), in Manaus.
} 
Cultural aspects, which are important in any communication process, as well as an improved interface between art, science and society, should be taken into consideration in science communication activities. Another goal to achieve is to recognize the value of the cultural and humanistic aspects of science, as well as the acknowledgement of popular and traditional knowledge. On the other hand, the direction pointed out by so-called "citizen science", which favors the collective learning and construction of knowledge and its social appropriation, indicates a scientific education integrated with a public engagement with science. One of the most effective ways to educate the young and the public about science is to put them in the role of researchers and make them use, even if it is at a restricted level, the methods of science in an effective dialogue between science, its actors and the public.

There is still a long way until we can declare that there exists a high level science communication and an adequate social appropriation of scientific and technological knowledge encompassing all Brazilian society. But the journey began long ago, with faltering steps in previous decades, becoming firmer in recent years. Overcoming the great challenges that were outlined here is a fundamentally collective task, that depends on the creation of effective public policies. But also, and most importantly, it depends on the collective action of scientists, teachers, science communicators, journalists, museum experts, students and all the people involved with scientific work and its communication. As João Cabral de Melo Neto beautifully poeticized: "A rooster on its own does not weave a morning; it will always need other roosters (...) so that the morning, starting from a fine web, can be weaved among all the roosters ${ }^{28}$ ".

\footnotetext{
${ }^{28}$ In Portuguese: "um galo sozinho não tece uma manhã, ele precisará sempre de outros galos (...) para que a manhã, desde uma teia tênue, se vá tecendo, entre todos os galos”.
}

\section{REFERENCES}

ALMEIDA C, BRITO F, FERREIRA R, MASSARANI L AND AMORIM L. 2015. Centros e Museus de Ciência do Brasil. Rio de Janeiro: ABCMC, Casa da Ciência/UFRJ e Museu da Vida.

ALMEIDA C, RAMALHO M, BUYS B AND MASSARANI L. 2011. La cobertura de la ciencia en América Latina: estudio de periódicos de elite en nueve países de la región. In: Moreno C (Ed), Periodismo y divulgación científica. Tendencias en el ámbito iberoamericano. Madrid: OEI and Biblioteca Nueva, p. 75-97.

BAUER M. 1998. La longue durée of popular science, 1830 - present. In: Deveze-Bethet D (Eds), La promotion de la culture scientifique: ses acteurs e leurs logiques. Paris : Publications de l'Université/Paris 7/Denis Diderot, p. 7592.

BELL P, LEWENSTEIN BV, SHOUSE A AND FEDER M (Eds). 2009. Learning Science in Informal Environments: People, Places, and Pursuits. Washington, DC: National Academies Press.

CASTELFRANCHI Y, MASSARANI L AND RAMALHO M. 2014. War, anxiety, optimism and triumph: a study on science in the main Brazilian TV news. JCOM, Journal of Science Communication 3: A1.

CASTELFRANCHI Y, VILELA E, MOREIRA I AND MASSARANI L. 2013. As opiniões dos brasileiros sobre C\&T: o paradoxo da relação entre informação e atitudes. História, Ciências, Saúde-Manguinhos 20: 1163-1183.

CORREIA CMF.1876. Conferências Populares (realizadas na Glória em 1876). 1876. Rio de Janeiro: Typ Imp Const J Villeneuve \& C.

COUTY L. 1879. Os estudos experimentais no Brasil. Revista Brazileira II: 215-239.

ESTEVES B. 2011. Os cientistas vão à imprensa: divulgação científica nos jornais brasileiros (1945-1964). In: Massarani L, Jurberg C and De Meis L (Eds), Um gesto ameno para acordar o país: a ciência no 'Jornal do Commercio' [19581962]. Rio de Janeiro: Museu da Vida / Fundação Oswaldo Cruz, p. 13-23.

ESTEVES B, MASSARANI L AND MOREIRA I. 2006. Ciência para Todos e a divulgação científica na imprensa brasileira entre 1948 e 1953. Rev Soc Bras Hist Ciênc 4(1): 62-85.

ESTEVES B, MASSARANI L AND MOREIRA I. 2007. La visite de Marie Curie à Rio de Janeiro en 1926 et la presse brésilienne. Rev Bras Hist Ciênc 5: 134-148.

FERNANDES AM. 1990. A construção da ciência no Brasil e a SBPC. Brasília: Editora UnB.

FERREIRA JR. 2014. Popularização da Ciência e Tecnologia e as Políticas Públicas no Brasil (2003-2012). PhD thesis, Programa de Pós-Graduação em Ciências Biológicas Biofísica, IBCCF / UFRJ. 
FONSECA MRF. 1996. As "Conferências Populares da Glória": a divulgação do saber científico. História, Ciência, Saúde - Manguinhos II/3: 135-166.

LINS A. 1956. Discurso de posse na Academia Brasileira (estudo sobre Roquette-Pinto). Rio de Janeiro: MEC.

LIVRO AZUL. 2010. IV Conferência Nacional de Ciência, Tecnologia e Inovação. Brasília: CGEE and MCT. http:// www.cgee.org.br/publicacoes/livroazul.php (visited on April 9, 2015).

LOPES MM. 1995. O Brasil descobre a pesquisa científica. Os museus e as ciências naturais no século XIX. São Paulo: Hucitec.

MARANDINO M. 2005. A pesquisa educacional e a produção de saberes nos museus de ciência. História, Ciências, Saúde - Manguinhos 12(Supl.): 161-181.

MARQUES VRB. 2005. Escola de homens de ciências: a Academia Científica do Rio de Janeiro, 1772-1779. Educar (UFPr), n. 25, p. 39-57.

MASSARANI L, AMORIM L, BAUER MW AND MONTES DE OCAA. 2012. Periodismo científico: reflexiones sobre la práctica en América Latina. Chasqui 120: 73-77.

MASSARANI LAND MOREIRA I. 2002. Aspectos históricos da divulgação científica no Brasil. In: Massarani L, Moreira I and Brito F (Eds), Ciência e público: caminhos da divulgação científica no Brasil. Rio de Janeiro: Casa da Ciência/UFRJ, p. 43-64.

MASSARANI L, MOREIRA I AND MAGALHÃES I. 2003. Quando a genética vira notícia: Um mapeamento da genética nos jornais diários. Ciênc Ambient 26: 141-148.

MEDEIROS F, RAMALHO M, CALDAS C AND MASSARANI L. 2013. Ciência e tecnologia em um programa de infotainment: uma análise de conteúdo da cobertura do Fantástico. InterCom: Rev Bras Ciênc Comun 36: 127-147.

MOREIRA IC. 2006. A inclusão social e a popularização da ciência e tecnologia no Brasil. Inclusão Social 1: 11-16.

MOREIRA I. 2008. Globo Ciência: Ciência, Tecnologia e Televisão. In: Garcia D and Brandão AP. Comunicação e Transformação Social. São Leopoldo: Editora Unisinos, p. 89-98.

MOREIRA I AND MASSARANI L. 1997. Cândido Baptista de Oliveira e a implantação do sistema métrico decimal no Brasil. Rev Soc Bras Hist Ciênc 18(18): 3-16.

MOREIRA I AND MASSARANI L. 1999. 'A divulgação científica e seus ciclos'. VI Reunião da Rede de Popularização da C\&T, RedPOP, Rio de Janeiro.
MOREIRA I AND MASSARANI L. 2001. A divulgação científica no Rio de Janeiro: Algumas reflexões sobre a década de 20. História, Ciências, Saúde-Manguinhos 7(3): 627-651.

MOREIRA I AND MASSARANI L. 2011. A divulgação científica no Jornal do Commercio (1958-1962). In: Massarani L, Jurberg C and De Meis L (Eds), Um gesto ameno para acordar o país: a ciência no 'Jornal do Commercio’ [1958-1962]. Rio de Janeiro: Museu da Vida / Fundação Oswaldo Cruz, p. 43-62.

MOREIRA I, MASSARANI L AND ARANHA J. 2008. Roquette-Pinto e a divulgação científica. In: Lima NT and Sá DM (Eds), Antropologia brasiliana - Ciência e educação na obra de Edgard Roquette-Pinto. Belo Horizonte e Rio de Janeiro: Editora UFMG e Editora Fiocruz.

MOREIRA IC AND VIDEIRAAAP. 1995. Einstein e o Brasil. Rio de Janeiro: Editora da UFRJ.

OLIVEIRA JC. 1998. Cultura científica no Paço de D. João - o adorador do Deus das ciências (1808-1821). PhD Thesis, Universidade de São Paulo.

OZORIO DE ALMEIDA M. 2002. A vulgarização do saber. In: Massarani L, Moreira I and Brito F (Eds), Ciência e público: caminhos da divulgação científica no Brasil. Rio de Janeiro: Casa da Ciência/UFRJ, p. 65-71.

RAMALHO M, POLINO C AND MASSARANI L. 2012. From the laboratory to prime time: science coverage in the main Brazilian TV newscast. JCOM, Journal of Science Communication 11: A1.

REZNIK G, MASSARANI L, RAMALHO MAND AMORIM L. 2014. Ciência na televisão pública: uma análise do telejornal Repórter Brasil. Alexandria 7: 157-178.

SÁ MR AND DOMINGUES HMB. 1996. O Museu Nacional e o ensino de ciências naturais no Brasil no século XIX. Rev Soc Bras Hist Ciênc 15: 79-87.

SILVA JP (Org). 2002. Autos da devassa - Prisão dos letrados do Rio de Janeiro - 1794. $2^{\mathrm{a}}$ ed., Rio de Janeiro: Eduerj.

VALENTE ME. 2008. Museus de Ciências e Tecnologia no Brasil: uma história da museologia entre as décadas de 1950 - 1970. PhD thesis. Universidade Estadual de Campinas.

WERNECK EF. 2002. E por falar em ciência... no rádio! In: Massarani L, Moreira I and Brito F (Eds), Ciência e público: caminhos da divulgação científica no Brasil. Rio de Janeiro: Casa da Ciência/UFRJ, p. 79-88. 